\title{
TANGGUNG J AWAB WALI TERHADAP ANAK YANG BERADA DI BAWAH PERWALIANNYA (SUATU PENELITIAN DI KOTA BANDA ACEH)*
}

\author{
Zahratul Idami \\ Fakultas Hukum Universitas Syiah Kuala \\ E-mail: idami_isa@yahoo.com
}

\begin{abstract}
The resut of the research shows that there were guardians who did not make the list of the children's property and also did not record all the changes of property of the children under their guardianship when he started the position. There were also trustees who did not give all property of the children even thoug their already reached the age of 18 and already get married. It was caused by some factors such as their lack of knowledge on his duty and responsibility toward the children under their guardianship, their opinion that the children were not capable enough to manage the money by himself due to their bad attitude. Lack of socialization;more feeling of relationship; unclear of mechanism of guardianship; unavailableof controlling institution which is really consent to the guardianship. The efforts can be done: a continous controlling and deep toward the guardians and the children under their guardianship. Also it is better if the government make a strict regulation related to the guardianship.
\end{abstract}

Keywords : responsibility, guardian, guardianship

\begin{abstract}
Abstrak
Hasil penelitian menunjukkan Wali ada yang tidak membuat daftar harta benda anak, tidak mencatat, belum menyerahkan seluruh harta anak, padahal anak telah berusia di atas 18 tahun atau telah menikah. Hal ini disebabkan berbagai faktor yaitu Kurangnya pengetahuan dari wali, pendapat wali bahwa anak memang belum bisa diberikan hartanya karena belum bisa mengatur atau mengelola uang sendiri, karena adanya sifat boros dalam diri anak tersebut, Kurangnya sosialisasi; Rasa kekeluargaan yang tinggi; Tidak Jelasnya mekanisme pengawasan terhadap wali; Belum adanya lembaga Pengawas yang benar-benar konsen terhadap perwalian. Upaya-upaya: sosialisasi secara kontinyu dan mendalam kepada para wali dan anak-anak yang berada di bawah perwalian, Sebaiknya pemerintah membentuk lembaga pengawas khusus, membuat aturan yang tegas untuk mengatur tentang mekanisme pengawasan terhadap anak dan harta anak yang berada di bawah perwalian seseorang.
\end{abstract}

Kata kunci: tanggung jawab, wali, perwalian

\section{Pendahuluan}

Tanggung jawab dan kewajiban wali terhadap anak yang berada di bawah perwalian diatur pada Pasal 51 ayat (3) sampai dengan ayat (5) UU No. 1 Tahun 1974 tentang PokokPokok Perkawinan. Pada ayat (3), wali wajib mengurus anak yang di bawah penguasaannya dan harta bendanya dengan sebaik-baiknya dengan menghormati agama dan kepercayaan anak itu, sedangkan ayat (4) mengatur bahwa wali

\footnotetext{
- Artikel ini merupakan artikel hasil penelitian yang dibiayai oleh APDM-APBA dengan Nomor Kontrak: 226/ H11.2/ APBM-APBA/ VI/ 2009
}

wajib membuat harta benda anak yang berada di bawah kekeuasaannya pada waktu memulai jabatannya dan mencatat semua perubahan-perubahan harta benda anak atau anak-anak itu. Pada ayat (5) juga ditentukan bahwa wali bertanggung jawab tentang harta benda anak yang berada di bawah perwaliannya serta kerugian yang ditimbulkan karena kesalahan atau kelalaiannya. Ketentuan Pasal 52 selanjutnya mengatur, bahwa wali tidak boleh memindahkan hak atau menggadaikan barang-barang tetap yang dimiliki anaknya yang belum berumur 18 tahun 
atau belum pernah kawin, kecuali apabila kepentingan anak menghendaki.

Perwalian juga diatur dalam ketentuan yang lain yaitu Kompilasi Hukum Islam (KHI) yang mengatur juga mengenai kewajiban wali yaitu pada Pasal 110 ayat (1) s.d. (4) yang mengatur bahwa pada wali berkewajiban mengurus diri dan harta anak yang di bawah perwaliannya dan berkewajiban memberikan bimbingan agama, pendidikan dan keterampilan lainnya. Wali dilarang mengikat, membebani dan mengasingkan harta anak yang berada di bawah perwaliannya, kecuali menguntungkan atau tidak dapat dihindarkan. Selain itu, wali bertanggung jawab terhadap harta anak dan mengganti kerugian yang timbul sebagai akibat kesalahan atau kelalaiannya. Pertanggungjawaban dari wali harus dibuktikan dengan pem-buktian setiap tahun sekali.

Ketentuan Pasal 33 dan Pasal 34 UU No. 23 Tahun 2002 tentang Perlindungan Anak juga menentukan, bahwa wali yang ditunjuk berdasarkan penetapan pengadilan atau Mahkamah dapat mewakili anak untuk melakukan perbuatan hukum, baik di dalam maupun di luar pengadilan untuk kepentingan yang terbaik bagi anak. Pada ayat (2) dan (3) mengatur bahwa wali waj ib mengelola harta milik anak yang bersangkutan untuk kepentingan anak dalam mau pun di luar pengadilan untuk kepentingan yang terbaik bagi anak.

Kompilasi Hukum Islam (KHI) sebagai hukum materiil bagi hakim pengadilan agama merupakan pedoman atau rujukan dalam membuat keputusan berkenaan dengan perkara yang menjadi kompetensi dari Pengadilan Agama. ${ }^{1}$ Kompilasi Hukum Islam (KHI) Pasal 1 huruf h dijelaskan makna perwalian yaitu sebagai suatu kewenangan yang diberikan kepada seseorang untuk melakukan sesuatu perbuatan hukum sebagai wakil untuk kepentingan dan atas nama anak yang tidak mempunyai kedua orang tua atau orang tua yang masih hidup tapi tidak cakap melakukan perbuatan hukum. Pengertian

Ghulam Muhammad, "Sistem Hukum Kewarisan dalam Kompilasi Hukum Islam, Warta Univertaria", Majalah IImiah Universitas Medan Area, No. 23, 2009, Universitas Medan Area, hlm 67 tersebut dapat ditafsirkan, bahwa apabila masih ada ibunya, dan dia cakap melakukan perbuatan hukum, maka ibunyalah yang bertindak sebagai wali, tidak perlu ditunjuk orang lain.

Kompilasi Hukum Islam Pasal 109 mengatur, bahwa pengadilan agama dapat mencabut hak perwalian seseorang atau badan hukum dan memidahkannya kepada pihak lain atas permohonan kerabatnya bila wali tersebut pemabuk, penjudi, pemboros, gila dan atau melalaikan atau menyalahgunakan hak dan wewenangnya sebagai wali demi kepentingan orang yang berada di bawah perwaliannya. Tugas dan tanggung jawab wali sebenarnya sangat berat, karena seseorang wali di samping harus mengurus anak tersebut juga harus menjaga dan memelihara harta benda anak yatim tersebut. Kewajibannya juga harus mencatat baik pengeluaran dan perubahan terhadap harta benda anak yang berada di bawah perwaliannya agar harta tersebut dapat diserahkan kembali kepada anak itu pada saat anak dewasa dalam keadaan baik dan jelas, sehingga tidak menimbulkan fitnah. Anak-anak yang masih di bawah umur yang ditinggal oleh orang tuanya oleh hukum dianggap belum cakap untuk melakukan perbuatan hukum, sehingga baginya diperlukan seorang wali yang akan mewakilinya dalam mengurus kepentingannya baik kepentingan yang bersifat pribadi ataupun kepentingan lain yang berkaitan dengan pendidikan, kesehatan dan lain-lain.

Pemerintah telah mengeluarkan UU No. 48 Tahun 2007 tentang Penetapan Perpu Nomor 2 Tahun 2007 tentang Penanganan Permasalahan Hukum dalam Rangka Pelaksanaan Rahabilitasi dan Rekonstruksi Wilayah dan Kehidupan Masyarakat di Provinsi Nanggroe Aceh Darussalam dan Kepulauan Provinsi Sumatera Utara. Perwalian dalam Perpu tersebut diatur pada Pasal 27 sampai dengan Pasal 32, namun pengaturannya lebih kepada harta anak bukan kepada pengawasan terhadap penggunaan harta anak oleh wali (untuk pengasuhan selama di bawah perwaliannya). Ketentuan Pasal 31 ayat (1) Perpu tersebut mengatur, bahwa anak di ba-wah umur yang orang tuanya telah meninggal atau tidak cakap bertindak menurut hukum, maka 
harta kekayaannya dikelola oleh wali sesuai dengan ketentuan peraturan perundang-undangan.

Pada tahun 2008 juga telah disahkan Qanun No. 11 Tahun 2008 tentang Perlindungan Anak. Kewajiban dan Larangan terhadap wali juga diatur dalam qanun ini yaitu dalam Pasal 21 ayat (1) yaitu bahwa wali berkewajiban untuk mengasuh anak yang berada di bawah perwaliannya, memberikan bimbingan agama, mengupayakan pendidikan dan keterampilan lainnya, mengupayakan pelayanan kesehatan; mengupayakan tempat tinggal, mengelola harta milik anak yang berada di bawah perwaliannya, membuat daftar harta benda/kekayaan milik anak yang berada di bawah perwaliannya pada waktu memulai jabatannya, mencatat semua perubahan-perubahan harta benda/kekayaan anak yang berada di bawah perwaliannya dan menyerahkan seluruh harta anak yang berada di bawah perwaliannya, jika anak tersebut telah berusia di atas 18 tahun atau telah menikah, kecuali anak tersebut tidak cakap berbuat menurut hukum. Wali dilarang untuk menjual/mengalihkan hak/menggadaikan barang-barang tetap yang dimiliki anak yang berada di bawah perwaliannya, kecuali demi kepentingan anak dan anak yang berada di bawah perwaliannya menghendaki; dan mengikat, membebani dan mengasingkan harta anak yang berada di bawah perwaliannya, kecuali menguntungkan atau jika tidak dapat dihindari (Pasal 21 ayat (2)).

Wali yang miskin/dhuafa dapat menggunakan harta anak yang berada di bawah perwaliannya untuk memenuhi kebutuhan makanan sehari-hari sebagaimana ditentukan Pasal 21 ayat (3). Semua ini diawasi oleh wali pengawas. Dalam qanun tersebut yang bertindak sebagai wali pengawas adalah Badan Baitul Mal. Ketentuan Pasal 58 menegaskan, bahwa setiap wali yang mengabaikan kewajiban sebagaimana dimaksud dalam Pasal 21 ayat (1) dan ayat (2) dipidana dengan pidana kurungan paling lama 6 (enam) bulan dan/atau denda paling banyak Rp. 50.000.000 (Iima puluh juta rupiah).

Kenyataan yang ada di kota Banda Aceh, masih banyak wali yang belum melakukan kewajiban dan tanggung jawabnya sesuai dengan ke- tentuan yang telah diatur, misalnya ada wali yang tidak membuat daftar harta benda anak yang berada di bawah kekuasaannya pada waktu memulai jabatannya mencatat semua perubahan harta benda anak atas anak-anak yang berada di bawah perwalian termasuk kerugian yang ditimbulkan karena kesalahan atau kelalaiannya atau kelalaian lainnya, dalam arti bahwa masih banyak wali yang melalaikan kewajiban dan tanggung jawabnya sesuai dengan ketentuan yang berlaku. Penelitian ini adalah penelitian lanjutan karena salah satu hasil penelitian sebelumnya yang dilakukan dengan judul "Penetapan Perwalian Bagi Anak Korban Tsunami oleh Mahkamah Syar'iah Kota Banda Aceh, menunjukkan salah satu hasil wawancara dengan seorang hakil Mahkamah Syar'iah Kota Banda Aceh yaitu Hafidhah, mengatakan bahwa "Peraturan yang tentang Perwalian, jangan hanya mengatur tanggung jawab dari wali saja tapi pengawasan terhadap wali juga harus diatur". ${ }^{2}$

\section{Perumusan masalah}

Berdasarkan uraian di atas maka penulis tertarik untuk membahas mengenai pelaksanaan tanggung jawab wali terhadap anak yang berada di bawah perwaliannya, Faktor-faktor yang menyebabkan wali lalai dalam melakukan kewajiban dan tanggung jawab terhadap anak yang berada di bawah perwaliannya dan upaya hukum yang dapat dilakukan terhadap wali yang melalaikan kewajiban dan tanggung jawabnya.

\section{Metode Penelitian}

Penelitian ini dilakukan di Kota Banda Aceh, lokasi ini dipilih sebagai lokasi penelitian karena lokasi ini banyak wali yang memohon penetapannya sebagai wali di Mahkamah Syar'iah dan banyak anak yang berada di bawah perwalian yang telah ditetapkan oleh Mahkamah Syar'iah Kota Banda Aceh. Penelitian ini dilakukan dalam dua tahap: pertama, penelitian kepustakaan (library Research) guna mencari data sekunder yaitu dengan mempelajari per-

Zahratul Idami, 2010, Penetapan Perwalian Bagi Anak Korban tsunami Oleh Mahkamah Syar'iah Kota Banda Aceh, Jurnal Media Hukum Vol. 17, No. 2 Desember 2010, Yogyakarta, hlm. 213 
aturan-peraturan yang telah ada dan mempelajari literatur-literatur berupa buku-buku dan makalah yang berhubungan dengan penelitian ini; dan kedua, penelitian lapangan (field research) guna mendapatkan data primer dengan cara mengumpulkan data melalui kuisioner dan mewawancarai beberapa responden dan informan yang ada hubungan dengan permasalahan penelitian.

Responden dalam penelitian ini meliputi wali sebanyak 100 orang, anak yang berada di bawah perwalian sebanyak 6 orang, sedangkan yang menjadi informan penelitian adalah Hakim Mahkamah Syar'iah (2 orang), Panitera Mahkamah Syar'iah (2 orang) dan Pegawai Baitul Mal (1 orang). Pada tahun 2005-2009 terdapat 323 penetapan perwalian di Mahkamah Syar'iah Kota Banda Aceh) dari 323 wali tersebut, maka yang diambil menjadi sampel untuk disebarkan kuisioner adalah 100 orang wali, selanjutnya di lakukan pengelompokan jawaban dari kuisioner itu, mana wali yang melakukan tanggung jawab dan kewajiban dan mana yang tidak, Ialu dilakukan pengelompokan alasan-alasan wali yang disebutkan dalam kuisioner tersebut. Wawancara dilakukan terhadap wali secara purposive sampling dengan melihat terlebih dahulu jawaban dari kuisioner yang dikelompokkan. Sebagai data pelengkap juga diwawancarai para informan yang mengerti dan mengetahui permasalahan yang diteliti. Data yang diperoleh dari penelitian lapangan dan penelitian kepustakaan dipadukan untuk kemudian dianalisis dengan menggunakan metode kualititatif. Data disajikan dalam bentuk deskriptif anali-sis.

\section{Pembahasan}

Perwalian adalah suatu bentuk perlindungan dengan otoritas penuh atas dasar tanggung jawab dan cinta kasih, untuk memberikan pertolongan atas ketidakmampuan seseorang dalam melakukan perbuatan-perbuatan hukum, baik yang berhubungan dengan harta maupun dengan dirinya. ${ }^{3}$ Hak-hak anak dalam Konvensi yang ditanda tangani oleh Presiden Republik In-

Alam, Andi Syamsu dan fauzan, 2008, Hukum Pengangkatan Anak perspektif Islam, J akarta: Pernada media Group, hlm 151 donesia (RI) di New York dan berdasarkan Keputusan Presiden RI No. 36 Tahun 1990, kemudian diakomodasikan dalam UU No. 23 Tahun 2002 tentang Perlindungan Anak. Ketentuan Pasal 2 UU No. 23 tahun 2002 dengan tegas mengatur, bahwa kepentingan yang terbaik bagi anak yang merupakan salah satu asas undangundang tersebut. Menurut Rika Lestari:

"Konvensi hak-hak anak tersebut memilki tiga prinsip yaitu: Prinsip dasar yang harus dijaga keseimbangannya. Dalam Prinsip ini anak memiliki hak untuk mendapatkan perlindungan dari eksploitasi, penyiksaan dan penelantaran, serta memiliki hak untuk mempengaruhi keputusankeputusan berdasarkan kepentingan terbaik mereka sebagai pertimbangan utama. Prinsip partisipasi di mana anak berhak untuk didengar pendapatnya dan pendapat tersebut dipertimbangkan dalam semua keputusan yang mempengaruhi mereka, pendapat anak tersebut diberi bobot sesuai dengan usia dan kematangan anak termasuk dalam prosedur peradilan dan administrasi. Prinsip bimbingan orang tua yaitu anak berhak untuk mendapatkan bimbingan dari orang tua atau wali hukumnya dalam pelaksanaan hak-haknya dalam suatu cara yang sesuai dengan kemampuan perkembangan anak dan orang tua bertanggung jawab untuk memberikan dukungan dan bantuan terhadap pendewasaan dan perkembangan anak. ${ }^{4}$

Anak-anak perlu mendapat perlindungan hukum demi menjamin hak-haknya. Anak merupakan aset negara yang paling penting untuk diperhatikan. Mereka adalah penerus cita-cita perjuangan bangsa. Kepada mereka digantung segala harapan di masa yang akan datang. Oleh sebab itu perhatian besar harus dicurahkan kepada mereka agar mereka dapat menyong-song hari esok dengan lebih baik.

Menurut Yanuar Farid Wismayanti:

"Anak dalam Hukum Indonesia merupakan kelompok masyarakat yang belum berusia 21 tahun dan belum menikah. Dalam UU No. 23 Tahun 2002 tentang Perlindungan Anak, membatasi usia anak 0-18 tahun.

\footnotetext{
Rika Lestari, "Tinjauan Yuridis Pelibatan Anak-anak dalam Penyelenggaraan Pemilu", Jurnal Mahkamah Konstitusi, Badan Kajian Konstitusi Universitas Riau, Vol. II No.1/J uni 2009, Mahkamah Konstitusi RI, hlm. 37.
} 
Dalam Perkembangannya anak mempunyai fase tumbuh kembang serta kebutuhan yang berbeda sesuai dengan usia serta tahapan tumbuh kembang anak tersebut. Fase Perkembangan anak dibagi dalam dua tahap yaitu tahap awal dan akhir. Tahap awal perkembangan anak mempunyai tugas sama dengan bayi, sehingga masuk kelompok balita, sedangkan fase tahap akhir, memilki tugas diantaranya membangun sikap yang sehat mengenai diri sendiri sebagai makhluk yang sedang tumbuh, mempelajari keterampi-lan fisik, belajar menyesuaikan diri, mengembangkan peran sosial, serta mencapai kebebasan pribadi. Anak juga memilki kebutuhan dari sisi fisik, emosional, sosial dan intelektual. Kebutuhan fisik merupakan kebutuhan yang berhubungan dengan pertumbuhan dan kesehatan fisik seperti makanan, udara segar, sinar matahari, dan aktifitas fisik. Kebutuhan emosional yakni terdapat tiga emosi dasar yang dimiliki manusia yairtu marah, senang dan takut. Kebutuhan sosial yaitu interaksi anak dengan orang-orang disekitarnya akan memberikan pengalaman hubungan sosial yang luas dan komplek. Kebutuhan Intelektual yaitu anak menginginkan dirinya berprestasi, ingin mengamati sesuatu secara serius, ingin mengetahui hal-hal baru, mencoba sesuatu serta menciptakan sesuatu. ${ }^{5}$

Anak perlu mendapatkan pendidikan, kesehatan dan perhatian kasih sayang di samping kebutuhan sandang dan pangan yang baik agar mereka dapat mengembangkan pribadinya secara benar.

Seorang anak belajar secara alamiah pada keluarganya terutama orang tua dan anggota keluarga lainnya. Apa yang didapat oleh seorang anak dalam keluarganya menjadi dasar yang tidak jarang menjadi mapan di kemudian hari. ${ }^{6}$ Pendidikan Agama dari orang tua untuk anakanak sangatlah penting dan diberikan sejak usia dini. Agama diharapkan dapat menjadi filter

5 Yanuar Farida Wismayanti, "Permasalahan dan Kebutuhan Anak yang berkonflik dengan Hukum di Lapas Anak Blitar", Jurnal Penelitian dan Pengembangan Kesejahteraan Sosial, Vol. 12 No. 01, J anuari-J uni 2007, Kemensos Rl, J akarta, hlm. 66.

6 Munzir Hitami, "Taat Hukum dan Pendidikan Akhlak", J urnal Hukum Respublika, Vol. 4 No. 1, 2004, hlm 7 bagi nak-anak untuk melakukan perbuatan yang tidak baik atau melanggar norma. ${ }^{7}$

Tanggung jawab terhadap pemeliharaan anak adalah tanggung jawab semua pihak (pemerintah masayarakat dan keluarga). Keluarga adalah pihak pertama yang paling bertanggung jawab dalam pemeliharaan anak. Perlakuan terhadap anak haruslah sangat hati-hati apalagi kalau anak itu bukan anak kandung, seperti anak yang berada di bawah perwalian kita, di mana dengan penetapan pengadilan atau Mahkamah Syar'iah anak tersebut telah menjadi tanggung jawab wali, maka haruslah seorang wali menjalankan semua kewajiban dan tanggung jawab yang telah ditentukan.

Dikatakan oleh Wahyu Sasonggo, bahwa

"Hukum Islam memiliki karakteristik yang berbeda dengan hukum sekuler, karena dalam hukum Islam terkandung nilai-nilai moral dan asas-asas yang merupakan perintah Allah swt, sehingga penafsiran dan penggunaannya tidak hanya didasar-kan pertimbangan rasional dan logika sematamata, tetapi juga harus digali apa yang menjadi asal-usul atau riwayat lahirnya surat-surat dalam Al-Quran yang dijadikan dasar acuan dan konteks atau aktualitasnya dengan moralitas agama Islam saat itu". 8

Dalam Hukum Islam, hukum terhadap anak kecil tetap berlaku sampai anak itu dewasa, sebagaimana firman Allah dalam Surat An-Nisa ayat (6) yang artinya:

"Dan hendaklah kamu menguj i anak yatim itu, sampai mereka cukup umur untuk menikah. Kemudian jika kamu berpendapat bahwa mereka sudah cerdas, sudah pandai memelihara harta maka hendaklah kamu serahkan kepada mereka itu hartahartanya".

\footnotetext{
Nikmah Rosidah, "Faktor Penyebab Penyalahgunaan Narkotika dan Psikotropika oleh Anak (Studi Pada Lembaga Pemasyarakatan Rajabasa Bandar Lampung)", Supremasi Hukum, Jurnal Penelitian Hukum, Vol II No. 1, 2006, Bengkulu, Fakultas Hukum Universitas Bengkulu, hlm. 74

8 Wahyu Sasonggo, "Kaj ian Terhadap Putusan Perkara No. 159/Pdt.G/2006/PA. Tnd Tentang Perbedaan Agama Faktor Determinan Terjadinya Perceraian", Jurnal Yudisial, Vol. I No. 3, Desember 2007, Komisi Yudisial RI, J akarta, hlm. 192.
} 
Perubahan seseorang dari seorang anak menjadi seorang yang tumbuh dewasa tentunya sangat di pengaruhi oleh lingkungannya. Menurut Dyah Wijaningsih, sebuah proses perubahan bisa lambat, namun bisa berlangsung cepat, sangat tergantung berbagai pada faktor di luar hukum sekaligus sosial, budaya, ekonomi, merupakan cakupan faktor yang turut serta menggenjot perubahan". ${ }^{9}$

Perwalian yang berlaku dalam Hukum Islam terhadap anak, serta merta sesudah lahirnya terdapat tiga macam, yaitu: perwalian terhadap mengasuh dan menyusukan, perwalian terhadap dirinya, perwalian terhadap hak miliknya. Perwalian terhadap diri seorang anak dilaksanakan untuk menjaga kesejahteraan anak itu sendiri, untuk mengawasi hal yang berhubungan dirinya dan segala macam kesejahteraan yang belum dapat diperolehnya sendiri.

Tugas wali termasuk mendidik anak, mencerdaskan pikirannya dan mengarahkan bakatnya untuk mempelajari keterampilan, atau melanjutkanya ke sekolah-sekolah kejuruan atau melanjutkan ke fakultas sesuai dengan bakatnya. Wali yang mengawasi kesejahteraan si anak adalah kerabat yang dekat, yang mempunyai hubungan darah dengan anak itu. Wali ini bertingkat-tingkat, sama dengan tingkatan mereka dalam menerima warisan. Wali yang didahulukan adalah mereka yang mempunyai hubungan kerabat yang sangat dekat, apabila mereka yang berhak menjadi wali itu berada dalam satu tingkat, maka didahulukan siapa yang lebih dekat hubungan kekeluargaannya. Hakim akan memilih siapa diantara mereka yang ada tersebut yang paling baik kelakuannya dan yang paling banyak pengalamannya, apabila yang menjadi wali itu tidak mempunyai harta, negara harus memberi-kan nafkah kepada mereka.

Sebuah hadis Nabi yang diriwayatkan oleh Abu Daud dari Abdullah bin Umar, yang artinya: "Cukuplah seseorang dianggap berdosa apabila menelantarkan orang-orang yang menjadi tanggungannya". Hadis ini menunjukkan, bahwa se-

Dyah Wijaningsih, "Perubahan social dan Hukum (dalam ancangan dan Pemikiran)", Jurnal Hukum, Vol 14, No. 1, 2004, Fakultas Hukum Universitas Islam Sultan Agung, hlm. 1 seorang tidak dibenarkan mengabaikan tanggung jawab terhadap orang-orang yang menjadi tanggungannya, apalagi sampai menyebabkan orang tersebut terlantar. Memelihara anak merupakan sesuatu yang diperintahkan dan ini merupakan tanggung jawab orang tua/ wali, karena tidak dibenarkan mengabaikan tanggung jawab tersebut. Rasulullah saw, dalam Abdillah ra, melarang berdoa yang tidak baik bagi anak-anak sebagaimana tidak ingin berdoa yang buruk bagi diri dan harta sendiri. Rasulullah saw per-nah menegaskan kepada seorang sahabat berna-ma Aus bin 'Ubadah yang memiliki banyak anak perempuan dan mendoakan agar mereka mati, maka Rasulullah saw menyatakan adanya barakah dalam pengasuhan anak-anak, merekalah pelipur lara, penghibur kala derita, rezeki mereka ditanggung oleh Allah. Pemeliharaan anak merupakan tanggung jawab orang tua untuk mengawasi, memberikan pelayanan yang semestinya, serta mencukupi kebutuhan hidup si anak dan pemeliharaan yang berupa pengawasan, pelayanan, serta pencukupan nafkah anak tersebut adalah bersifat terus menerus sampai anak itu dewasa.

Wali dalam pengertian Perpu Nomor 2 Tahun 2007 tentang Penanganan Permasalahan Hukum dalam Rangka Pelaksanaan Rahabilitasi dan Rekonstruksi Wilayah dan Kehidupan Masyarakat di Provinsi Nanggroe Aceh Darussalam dan Kepulauan Provinsi Sumatera Utara ditentukan dalam Pasal 1 angka 5 yaitu wali adalah orang atau badan yang menjalankan kekuasaan asuh sebagai orang tua terhadap anak. Perwalian dalam Perpu ini cenderung hanya akan membicarakan harta peninggalan si ahli waris, baik kepada ahli warisnya langsung maupun kepada ahli waris berupa badan atau lembaga.

Perpu tersebut juga telah mengatur dengan tegas bahwa Baitul Mal atau Balai Harta Peninggalan adalah sebagai pengelola harta bagi harta yang ahli warisnya tidak diketahui keberadaannya dan juga sebagai wali pengawas. Sebelumnya, kewenangan Baitul Mal atau Balai Harta Peninggalan dalam mengelola harta yang tidak lagi ada ahli warisnya, belum diatur secara jelas dan tegas, baik sebagai wali pengelola harta maupun sebagai wali pengawas. Penetapan un- 
tuk pencabutan hak wali yang sudah ada karena diketahui terjadi penyalahgunaan, pemborosan atau merugikan kepentingan anak.

Kewenangan Baitul Mal sebagai wali pengawas diatur dalam Pasal 32 ayat (1) Perpu ini. Ketentuan Pasal 27 mengatur bahwa harta kekayaan yang pemiliknya dan ahli warisnya tidak diketahui keberadaannya, karena hukum, berada di bawah pengawasan dan pengelolaan Baitul Mal atau Balai Harta Peninggalan sampai ada penetapan pengadilan. Baitul Mal untuk kaum muslim, pengelolaan harta non muslin dilakukan oleh Balai Harta Peninggalan. Terkait dengan hal ini, Baitul Mal atau Balai Harta Peninggalan mengajukan permohonan kepada pengadilan untuk ditetapkan sebagai pengelola terhadap harta kekayaan yang tidak diketahui pemilik atau ahli warisnya, sesuai dengan Pasal 28, apabila harta tersebut sudah dikelola oleh Baitul Mal atau Balai Harta Peninggalan tetapi di kemudian hari, dapat diketahui kembali orang yang dinyatakan tidak diketahui keberadaannya, maka yang bersangkutan dapat mengajukan permohonan keberatan kepada pengadilan atau Mahkamah Syar'iyah (Pasal 29). Baitul Mal atau Balai Harta Peninggalan wajib mengembalikan harta kekayaan yang dikelolanya disertai Berita Acara Penyerahan, apabila kemudian pengadilan mengabulkan permohonan yang bersangkutan terkait pengajuan permohonan keberatannya.

Anak di bawah umur yang orang tuanya telah meninggal atau tidak cukup cakap untuk bertindak menurut hukum, maka harta kekayaannya dikelola oleh wali dengan ketentuan perundang-undangan, tetapi jika dalam hal ini, pihak keluarga tidak mengajukan permohonan penetapan wali, maka Baitul Mal atau Balai Harta Peninggalan sebagai wali pengawas mengajukan permohonan penetapan wali kepada pengadilan/Mahkamah Syar'iyah (Pasal 32). Permohonan penggantian wali dapat diajukan oleh Baitul Mal atau Balai Harta Peninggalan kepada pengadilan/ Mahkamah Syar'iyah.

Qanun No. 11 Tahun 2008 tentang Perlindungan Anak telah disahkan di wilayah Aceh. Dalam qanun ini ditentukan bagaimana tanggung jawab dan kewajiban dari wali terhadap anak yang berada di bawah perwaliannya, de- mikian juga apabila wali memalaikan kewajibannya, maka wali juga akan dikenakan sanksi. Hal ini dapat dilihat dalam beberapa Pasal yang ditentukan dalam qanun tersebut yaitu Pasal 19 ayat (1) yang menetapkan syarat-syarat seorang wali, meliputi beragama Islam bagi anak yang orang tuanya beragama Islam, balig dan berakal, tidak pernah dihukum karena menyalahgunakan kewenangan sebagai wali, tidak pernah di hukum dengan hukuman pidana 3 (tiga) tahun penjara atau lebih atau hukuman lain yang setara dengan itu dan amanah. Suatu badan/ lembaga juga dapat ditunjuk menjadi wali apabila memenuhi syarat-syarat meliputi: berasaskan Islam bagi anak yang beragama Islam, berbadan hukum dan berdomisili di Aceh; dan memiliki sarana dan fasilitas yang layak (Pasal 19 ayat (2)). Tugas seorang wali adalah untuk merawat, mengasuh dan membina anak/anak yatim serta mengelola hak warisnya dan wali bertanggung jawab atas kesejahteraan dan harta benda anak/anak yatim yang berada di bawah perwaliannya (Pasal 20 ayat (1) dan (2))

Kewajiban dan larangan terhadap wali juga diatur dalam qanun ini yaitu pada Pasal 21 ayat (1) yang mengatur bahwa wali berkewajiban untuk:

a. Mengasuh anak yang berada di bawah perwaliannya;

b. Memberikan bimbingan agama;

c. Mengupayakan pendidikan dan keterampilan lainnya;

d. Mengupayakan pelayanan kesehatan;

e. Mengupayakan tempat tinggal;

f. Mengelola harta milik anak yang berada di bawah perwaliannya;

g. Membuat daftar harta benda/ kekayaan milik anak yang berada di bawah perwaliannya pada waktu memulai jabatannya;

h. Mencatat semua perubahan-perubahan harta benda/kekayaan anak yang berada di bawah perwaliannya; dan

i. Menyerahkan seluruh harta anak yang berada di bawah perwaliannya jika anak tersebut telah berusia di atas 18 tahun atau telah menikah, kecuali anak tersebut tidak cakap berbuat menurut hukum.

Wali dilarang untuk menjual/mengalihkan hak/ menggadaikan barang-barang tetap yang dimili- 
ki anak yang berada di bawah perwaliannya, kecuali demi kepentingan anak dan anak yang berada di bawah perwaliannya, menghendaki dan mengikat, membebani dan mengasingkan harta anak yang berada di bawah perwaliannya, kecuali menguntungkan atau jika tidak dapat dihindari (Pasal 21 ayat (2)).

Wali yang miskin/dhuafa dapat menggunakan harta anak yang berada di bawah perwaliannya untuk memenuhi kebutuhan makanan sehari-hari Pasal 21 ayat (3). Semua ini diawasi oleh wali pengawas. Dalam qanun tersebut yang bertindak sebagai wali pengawas adalah Badan Baitul Mal.

Pengasuhan di dalam keluarga berfungsi untuk menjamin tumbuh kembang anak ke arah kehidupan yang lebih baik secara fisik, mental, sosial dan emosional serta intelektual anak. Pengasuhan di dalam keluarga dilaksanakan dengan memperhatikan prinsip-prinsip yang mengutamakan kepentingan terbaik anak, menjunjung tinggi ketentuan syariat Islam dan adat istiadat. prinsip-prinsip tersebut meliputi: pertama, memberikan kesempatan yang sama kepada anak laki-laki dan perempuan yang membutuhkan untuk mendapat pelayanan yang sama; kedua, menghargai dan memberi perhatian kepada anak dalam kapasitas sebagai individu sekaligus juga sebagai anggota masyarakat; ketiga, menyelenggarakan fungsi pelayanan yang bersifat pencegahan, perlindungan, pelayanan dan rehabilitasi serta pengembangan; keempat, memberikan kesempatan memperoleh pendidikan yang bertujuan meningkatkan kemampuan intelektual, spiritual, dan akhlak; kelima, menyediakan pelayanan kesejahteraan sosial verdasarkan kebutuhan dasar anak untuk meningkatkan fungsi sosial anak; dan keenam, memberikan kesempatan kepada anak untuk berpartisipasi secara aktif dalam usaha-usaha pertolongan yang diberikan (Pasal 7 ayat (2) s.d. ayat (4) Qanun No. 11 Tahun 2008 tentang Perlindungan Anak).

\section{Tanggung J awab Wali Terhadap Anak yang Berada di Bawah Perwaliannya}

Masyarakat Aceh mengenal ada tiga macam wali. Pertama, Wali Pengasuh Anak. Wali ini bertangung jawab atas pengasuhan seharihari dan pertumbuhan anak yang bersangkutan dan wali pengasuh ini tidak berhak untuk mewakili atau bertindak atas nama anak tersebut. Wali pengasuh anak biasanya diambil dari ibunya anak jika masih hidup, perempuan dari pihak ibu. Kedua, Wali Warisan. Wali ini bertanggung jawab terhadap pengelolaan warisan anak atau harta benda lainnya dan menjamin bahwa harta kekayaan anak digunakan untuk keperluan sehari-hari anak tersebut. Wali warisan biasanya dari pihak laki-laki dari pihak ayah (Paman). Ketiga, Wali Perkawinan. Wali ini hanya berlaku bagi pihak anak perempuan dan menurut Mazhab Syafi'i wali ini harus laki-laki.

Pada Prinsipnya seorang wali dengan kewenangannya harus senantiasa berorientasi kepada pemeliharaan dan kemaslahatan orang yang berada di bawah perwaliannya. Wali juga harus dari keluarga terdekat karena persoalan pribadi dan harta merupakan persoalan yang cukup rumit. ${ }^{10}$

Penulis, sebelum menjelaskan tentang pelaksanaan tanggung jawab wali terhadap anak yang berada di bawah perwalian di kota Banda Aceh terlebih dahulu dijelaskan mengenai prosedur seseorang menjadi wali yang pada akhirnya ditetapkan dengan putusan Mahkamah Syar'iah berupa penetapan seorang menjadi wali. Prosedur untuk menyatakan bahwa seorang anak akan berada di bawah perwalian seorang wali atau menetapkan seseorang menjadi wali dari seoarang anak adalah dengan cara mengajukan permohonan ke pengadilan. Proses penetapan seorang wali meliputi: pertama, caIon wali mengajukan permohonan penetapan wali dengan menyebutkan identitas lengkap dirinya dan anak-anak yang berada di bawah perwaliannya, serta hubungan perwaliannya; kedua, Berdasarkan berkas ini, Mahkamah Syar'iah menetapkan permohonan sebagai perkara permohonan (volunteer) yang tidak ada sengketa dan tidak ada lawan, tetapi bersifat sepihak, yakni pemohon saja; ketiga, Majelis hakim, di hari persidangan, memeriksa permohonan perwalian dengan mendengar keterangan Pemohon

10 Muhammad Amin Summa, 2004, Hukum Keluarga Islam di Dunia Islam, J akarta: Raj awali Press, hlm.135 
(wali) dan saksi-saksi yang dapat menguatkan permohonan Pemohon. Biasanya, dibutuhkan dua orang saksi; keempat, Majelis Hakim, apabila dianggap perlu, dapat mendengarkan keterangan si anak, yang dimohonkan perwaliannya; Kelima, Majelis hakim member-kan penetapan tentang perwalian yang diajukan, apabila permohonan dapat dikabulkan; dan keenam, Majelis hakim memberikan penjelasan tentang hak dan kewajiban serta tangungjawab Wali terhadap anak yang berada di bawah perwaliannya termasuk pula hak si anak nanti untuk menggugat ganti rugi dari wali bila hartanya tidak dapat dipertanggungjawabkan oleh si wali.

Penetapan perwalian di Kota Banda Aceh dilakukan dengan Keputusan Mahkamah Syar'iah Kota Banda Aceh berdasarkan permohonan dari pemohon dengan syarat-syarat yang telah ditentukan. Syarat-syarat yang harus dipenuhi oleh pemohon untuk penetapan perwalian tersebut meliputi: pertama, surat keterangan kematian orang tua dari anak yang dimohonkan penetapan perwalian tersebut; kedua, surat rekomendasi dari Geuchik yang menjelaskan hubungan pemohon dan anak, serta merekomendasikan agar pemohon diakui untuk menjadi wali dari anak tersebut; ketiga, surat keterangan dari camat yang mendukung surat geuchik dan menyetujui permohonan perwalian serta mendukung permohonan penetapan perwalian dari pemohon; keempat, surat permohonan penetapan perwalian; kelima, fotocopy Kartu Tanda Penduduk (KTP); keenam, menghadiri langsung sidang penetapan perwalian bagi pemohon; dan ketujuh, menghadirkan dua orang saksi. ${ }^{11}$

Setelah semua syarat terpenuhi, maka permohonan dapat diajukan ke Mahkamah Syar'iah dengan membawa semua berkas tersebut. Katua Mahkamah selanjutnya akan menunjuk hakim yang akan mengadili permohonan dengan menetapkan tanggal dan waktu sidang. Panitera kemudian akan menghubungi pemohon untuk memberitahukan jadual sidang. Sidang dilakukan dalam waktu 30 hari sejak permohonan diajukan ke Mahkamah, melalui acara cepat dan tidak dipungut biaya perkara.

11 Wawancara dengan Panitera Mahkamah Syar'iah Kota Banda Aceh, tanggal 11 J uli 2009
Hakim yang ditunjuk, selanjutnya akan meneliti permohonan dan dokumen pendukung yang telah dilengkapi, saksi yang telah dihadirkan harus memberikan keterangan yang bisa meyakinkan hakim tentang kedekatan hubungan pemohon dengan anak yang mendukung permohonan penetapan perwalian. Hakim selanjutnya akan menjelaskan tanggung jawab dari wali berdasarkan ketentuan yang berlaku dan konsekuensi yang harus diterima, jika tidak menjalankannya. Apabila permohonan penetapan tersebut dikabulkan, maka hakim akan mengeluarkan keputusan yang berisi tentang pengabulan permohonan pemohon, penetapan bahwa orang tua anak meninggal, penetapan bahwa anak yang bersangkutan berada di bawah perwalian pemohon dan menghukum pemohon untuk melaksanakan tanggung jawab perwaliannya terhadap anak tersebut dan harta bendanya sebagaimana yang ditentukan oleh peraturan perwalian.

Penetapan perwalian di kota Banda Aceh dan diajukan ke Mahkamah Syar'iah jumlah pemohonnya bervariasi dari tahun 2005 sampai dengan tahun 2009. Jumlah permohonan penetapan perwalian ke Mahkamah Syar'iah, pencabutan wali dan banding terhadap pencabutan wali dari tahun 2004 sampai dengan tahun 2008 dapat dilihat pada tabel di bawah ini:

Tabel 1

Penetapan perwalian, pencabutan kekuasaan dan banding terhadap pencabutan wali

\begin{tabular}{|c|c|c|c|c|}
\hline No. & Tahun & $\begin{array}{c}\text { Penetapan } \\
\text { Perwalian }\end{array}$ & $\begin{array}{c}\text { Pencabutan } \\
\text { Perwalian }\end{array}$ & Banding \\
\hline 1. & 2005 & 112 & - & - \\
\hline 2. & 2006 & 83 & - & - \\
\hline 3. & 2007 & 91 & 1 & \\
\hline 4. & 2008 & 14 & 1 & 1 \\
\hline 5. & 2009 & 23 & - & - \\
\hline \multicolumn{2}{|c|}{ J umlah } & 323 & 2 & 1 \\
\hline
\end{tabular}

Sumber: Mahkamah Syar'iah Kota Banda Aceh

Berdasarkan tabel di atas diketahui bahwa pada tahun 2005 permohonan penetapan perwalian jumlahnya mencapai 112, dibandingkan tahun sesudahnya. Hal ini disebabkan pada saat itu, banyak sekali anak-anak yang kehilangan orang tuanya baik karena orang tuanya meninggal atau hilang pada saat Bencana Gempa dan Tsunami terjadi. Pada tahun 2006 pe- 
netapan perwalian berjumlah 83 penetapan dan kemudian pada tahun 2007 berjumlah 91 penetapan, dan pada tahun 2008 berjumlah 14 penetapan sampai bulan Oktober 2008 dan tahun 2009 ada 23 penetapan sampai bulan November 2009. Berdasarkan wawancara yang dilakukan terhadap wali dan anak yang berada di bawah perwalian dapat diketahui bahwa masih banyak wali belum bertanggung jawab secara penuh dan masih ada yang belum melaksanakan kewajiban terhadap anak yang berada di bawah perwaliannya.

Tanggung jawab dan kewajiban yang belum dilaksanakan oleh sebagian wali terdiri dari: pertama, wali ada yang tidak membuat daftar harta benda anak yang berada dibawah kekuasaannya pada waktu memulai jabatannya dan tidak mencatat semua perubahan-perubahan harta benda anak/kekayaan anak yang berada di bawah perwaliannya; kedua, wali ada yang belum menyerahkan seluruh harta anak yang berada di bawah perwaliannya padahal anak telah berusia di atas 18 tahun atau telah menikah; dan ketiga, masih ada wali yang tidak bertanggung-jawab tentang harta benda anak yang berada dibawah perwaliannya serta kerugian yang ditimbulkan karena kesalahan atau kelalaiannya. Semua data ini dapat dilihat pada tabel berikut ini:

Tabel 2

Hasil Kuisioner dan Wawancara dengan wali

\begin{tabular}{|c|c|c|c|c|}
\hline No & $\begin{array}{l}\text { Hasil Kuisioner } \\
\text { Terhadap Wali }\end{array}$ & $\underset{\text { Wali }}{J}$ & $\begin{array}{c}\text { J awa } \\
\text { ban }\end{array}$ & Keterangan \\
\hline 1. & $\begin{array}{l}\text { Mengasuh anak yang } \\
\text { ada di bawah per- } \\
\text { waliannya; }\end{array}$ & 100 & Ada & \\
\hline 2. & $\begin{array}{l}\text { Memberikan bimbi- } \\
\text { ngan agama; }\end{array}$ & 100 & Ada & \\
\hline 3 & $\begin{array}{l}\text { Mengupayakan pen- } \\
\text { didikan dan kete- } \\
\text { rampilan lainnya }\end{array}$ & 100 & Ada & \\
\hline 4 & $\begin{array}{l}\text { Mengupayakan pela- } \\
\text { yanan kesehatan }\end{array}$ & 100 & Ada & \\
\hline 5 & $\begin{array}{l}\text { Mengupayakan tem- } \\
\text { pat tinggal }\end{array}$ & 100 & Ada & $\begin{array}{l}\text { Tinggal bersa- } \\
\text { ma wali }\end{array}$ \\
\hline 6 & $\begin{array}{l}\text { Mengelola harta mi- } \\
\text { lik anak yang berada } \\
\text { di bawah perwalian- } \\
\text { nya }\end{array}$ & $\begin{array}{l}40 \\
60\end{array}$ & $\begin{array}{l}\text { Ada } \\
\text { Tidak }\end{array}$ & $\begin{array}{l}\text { Karena wali } \\
\text { miskin, teta- } \\
\text { pi tidak men- } \\
\text { catat, mema- } \\
\text { kai harta wali } \\
\text { sendiri }\end{array}$ \\
\hline 7 & $\begin{array}{l}\text { Dibuat daftar harta } \\
\text { benda/ kekayaan mi- } \\
\text { lik anak yang bera- }\end{array}$ & 95 & Tidak & $\begin{array}{l}\text { Tidak menge- } \\
\text { tahui itu pen- } \\
\text { ting; tak men- }\end{array}$ \\
\hline
\end{tabular}

\begin{tabular}{|c|c|c|c|c|}
\hline & $\begin{array}{l}\text { da di bawah per-wa- } \\
\text { liannya pada waktu } \\
\text { memulai jabatan- } \\
\text { nya }\end{array}$ & 5 & $\mathrm{Ya}$ & $\begin{array}{l}\text { catat karena } \\
\text { ada yang me- } \\
\text { nggunakan } \\
\text { harta sendiri; } \\
\text { tidak begitu } \\
\text { lengkap, se- } \\
\text { perti pembu- } \\
\text { kuan biasa }\end{array}$ \\
\hline 8 & $\begin{array}{l}\text { Mencatat semua pe- } \\
\text { rubahan-perubahan } \\
\text { harta benda/ keka- } \\
\text { yaan anak yang ber- } \\
\text { ada di bawah per- } \\
\text { waliannya }\end{array}$ & $\begin{array}{l}95 \\
5\end{array}$ & $\begin{array}{l}\text { Tidak } \\
\text { Ya }\end{array}$ & $\begin{array}{l}\text { Tidak menge- } \\
\text { tahui \& ada } \\
\text { yang menggu- } \\
\text { nakan harta } \\
\text { sendiri; tidak } \\
\text { begitu leng- } \\
\text { kap seperti } \\
\text { pembukuan } \\
\text { biasa }\end{array}$ \\
\hline 9 & $\begin{array}{l}\text { Menyerahkan selu- } \\
\text { ruh harta anak yang } \\
\text { berada di bawah } \\
\text { perwaliannya jika } \\
\text { anak tersebut telah } \\
\text { berusia di atas } 18 \\
\text { tahun atau telah } \\
\text { menikah, kecuali } \\
\text { anak tersebut tidak } \\
\text { cakap berbuat me- } \\
\text { nurut hukum. }\end{array}$ & 90 & Tidak & $\begin{array}{l}\text { Usia anak ma- } \\
\text { sih di bawah } \\
\text { umur, ada ke- } \\
\text { khawatiran } \\
\text { anak tersebut } \\
\text { boros; diang- } \\
\text { gap anak su- } \\
\text { dah bisa di- } \\
\text { percaya }\end{array}$ \\
\hline 10 & $\begin{array}{l}\text { Menjual/ mengalih- } \\
\text { kan hak/ menggadai- } \\
\text { kan barang-barang } \\
\text { tetap yang dimiliki } \\
\text { anak yang berada di } \\
\text { bawah perwalian- } \\
\text { nya, kecuali untuk } \\
\text { kepentingan anak }\end{array}$ & 85 & Tidak & $\begin{array}{l}\text { Tidak dalam } \\
\text { penguasaanny } \\
\text { a dan masih } \\
\text { ada harta wali } \\
\text { untuk kebutu- } \\
\text { han anak ter- } \\
\text { sebut }\end{array}$ \\
\hline 11 & $\begin{array}{l}\text { Mengikat, membe- } \\
\text { bani dan mengasing- } \\
\text { kan harta anak yang } \\
\text { berada di bawah } \\
\text { perwaliannya }\end{array}$ & 15 & $\mathrm{Ya}$ & $\begin{array}{l}\text { Menyewakan; } \\
\text { Menggadaikan } \\
\text { untuk kepen- } \\
\text { tingan anak }\end{array}$ \\
\hline
\end{tabular}

Berdasarkan hasil penelitian yang diperoleh menunjukkan bahwa masih sangat sedikit wali yang mencatat harta anak yang berada di bawah perwaliannya dari 100 kuisioner yang disebarkan ternyata hanya ada 5 orang wali yang mecatat semua harta anak yang berada di bawah perwaliannya. J adi hanya ada 5\% Wali yang membuat daftar harta dan mencatatnya dan ada di antara wali yang menggunakan harta anak yang di bawah perwaliannya untuk kepentingan anak tersebut (wali yang miskin 20 (20\%) dan selebihnya wali menggunakan harta-nya sendiri untuk keperluan anak sedangkan harta anak yang berada di bawah perwaliannya tersebut tidak digunakan dengan alasan ada harta yang tidak berada di bawah penguasaan-nya (50\%) dan ada yang mengatakan tidak akan 
menggunakan harta tersebut selama wali masih mempunyai harta untuk bisa menghidupi atau menyekolahkan anak tersebut (25\%). Terdapat beberapa wali yang tidak meyerahkan harta kepada anaknya karena usia anak masih di bawah umur.

Beberapa wali tersebut ada yang mengatakan bahwa harta anak yang berada di bawah perwaliannya tidak ada padanya karena dia hanya mengasuh anak saja, sedangkan harta anak itu berada pada pamannya. Selama ini dia menggunakan hartanya sendiri untuk membiayai kebutuhannya dan sekolahnya. ${ }^{12}$ Beberapa wali juga ada yang mengatakan, bahwa wali tidak mengetahui bahwa dia harus membuat daftar harta benda anak dan mencatat semua harta anak dari memulai jabatannya dan juga tidak mengetahui, bahwa harus mencatat semua perubahan-perubahan dari harta anak tersebut. ${ }^{13}$ Demikian juga halnya dengan jawaban wali yang menggunakan harta anak yang berada di bawah perwaliannya yaitu sebuah honda yang dijual untuk membayar uang les dan keperluan yang lain yang digunakan oleh wali untuk anak tersebut, namun wali tidak mencatatnya karena menurut wali uang dan harta pribadinyapun sudah banyak habis digunakan untuk keperluan anak yang berada di bawah perwaliannya, jadi tidak perlu dicatat penggunaan harta tersebut. ${ }^{14}$ Anak yang berada di bawah perwalian seorang wali ada yang mengatakan bahwa mereka sudah sangat senang ada orang yang mengurusnya, jadi jika hartanya dipakai untuk keperluannya, maka dia tidak akan menuntut, bahkan menurutnya dia sangat sedih, jika walinya tidak menggunakan hartanya untuk membiayai hidupnya, karena dia merasa berhutang budi. ${ }^{15}$ Berdasar hasil wawancara juga diperoleh bahwa ada wali yang belum menyerahkan harta anak ketika anak sudah berusia 18 tahun, hal itu dilakukan karena anak tersebut boros dan belum bisa mengelola hartanya sendiri, ditakutkan

12 Wawancara dengan wali di kota Banda Aceh tanggal 20 J uli 2009

13 Wawancara dengan wali di kota Banda Aceh tanggal 22 J uli 2009

14 Wawancara dengan wali di kota Banda Aceh, tanggal 24 Juli 2009

15 Wawancara dengan anak yang berada di bawah perwalian di kota Banda aceh, tanggal 27 J uli 2009 nantinya malah anak tersebut akan menjual hartanya untuk hal-hal yang tidak perlu atau bukan untuk kebutuhan pokok. ${ }^{16}$

Menurut pihak Mahkamah, peraturan perwalian jangan hanya mengatur tanggung jawab saja, tetapi pelaksanaan pengawasan juga harus diatur. ${ }^{17}$ Selama ini peraturan perwalian masih terbatas pada putusan hakim yang menghukum wali untuk melaksanakan tanggung jawab perwaliannya, akan tetapi pengawasan terhadap pelaksanaan tanggung jawab itu tidak dilakukan, sehingga tidak akan bisa diketahui bahwa wali melakukan atau tidak tanggung jawabnya, demikian juga dengan harta anak yang berada di bawah perwaliannya juga tidak ada pengawasan apakah digunakan untuk kepentingan anak yang berada di bawah perwaliannya atau digunakan untuk hal lain yang bukan untuk kepentingan anak tersebut, semuanya tidak diketahui. Baru diketahui, jika ada yang memohonkan pencabutan perwalian, seharusnya tanpa permohonan tersebut, berdasarkan pengawasan yang dilakukan wali tersebut bisa dicabut perwaliannya atau menghukum untuk membayar kerugian dari harta anak yang digunakan bukan untuk kepentingan anak tersebut. ${ }^{18}$

\section{Faktor-Faktor yang Menyebabkan Wali Lalai dalam Melakukan Kewajiban dan Tanggung J a- wab Terhadap Anak yang berada di bawah Perwaliannya}

Faktor-faktor yang menyebabkan wali belum melakukan kewajiban (membuat daftar harta anak dan mencatatnya, dan tanggung jawab sepenuhnya terhadap anak yang berada di bawah perwaliannya adalah karena beberapa hal. Pertama, faktor interen (faktor penyebab yang berasal dari dalam diri wali itu sendiri). Faktor ini terjadi karena adanya anggapan wali terhadap tidak pentingnya catatan harta anak yang berada di bawah perwaliannya. Wali menganggap tidak pentingnya pembuatan daftar harta dan pencatatan harta anak tersebut karena me-

16 Wawancara dengan wali di kota Banda Aceh, tanggal 25 Juli 2009

17 Wawancara dengan Panitera Mahkamah Syar'iah Kota Banda Aceh, tanggal 29 J uli 2009

18 Wawancara dengan staf dari Mahkamah Syar'iah Kota Banda Aceh, tanggal 29 J uli 2009 
nurutnya ketika di pengadilan ada hakim menjelaskan tanggung jawabnya dan kewajibannya tetapi menurutnya pencatatan itu tidak begitu penting, sebab dia tidak akan menggunakan uang itu. Kurangnya pengetahuan dari wali terhadap kewajiban dan tanggung jawabnya terhadap anak di bawah perwaliannya, meskipun dia mendengar apa yang dibacakan oleh hakim pada saat permohonannya menjadi wali dikabulkan, namun karena pendidikannya rendah, maka dia tidak mengerti apa yang dibacakan hakim, wali tersebut malu untuk bertanya. Pendapat wali yang menganggap bahwa anak yang berada di bawah perwaliannya memang belum bisa diberikan hartanya meskipun dia sudah berusia 18 tahun karena anak masih belum bisa mengatur atau mengelola uang sendiri, karena adanya sifat boros dalam diri anak tersebut. ${ }^{19}$

Kedua, faktor ektern (faktor yang berasal dari luar diri wali). Faktor ini terjadi karena kurangnya sosialisasi dari Intansi Terkait terhadap Aturan Perwalian (Penerapan sanksi dan sebagainya), rasa kekeluargaan yang tinggi dari anak untuk tidak melaporkan orang yang telah menjadi wali bagi dirinya apabila wali bertindak tidak baik terhadap diri dan hartanya, tidak jelasnya mekanisme pengawasan terhadap wali dan Belum adanya lembaga Pengawas yang benarbenar konsen terhadap perwalian (Baitul Mal ada tugas pokok yang lain yang lebih berat).

Qanun tentang Perlindungan Anak yang telah disahkan pada tanggal 30 Desember 2008 dalam pemberlakuannya masih banyak masyarakat yang belum mengetahuinya terutama wali, apalagi qanun tersebut sudah memuat sanksi pidana terhadap wali yang lalai dalam menjalankan tanggung jawab dan kewajibannya. Menurut isi kuisioner dari 100 wali sebagian besar $(80 \%)$ tidak mengetahui bahwa harus adanya catatan yang lengkap terhadap daftar harta anak yang berada di bawah perwaliannya. Pada prinsipnya wali dalam menjalankan kewajibannya menganggap anak tersebut seperti anaknya sendiri.

Rasa kekeluargaan yang tinggi dari anak untuk tidak melaporkan orang yang telah men-

\footnotetext{
${ }^{19}$ Wawancara dengan wali tanggal 25 J uli 2009
}

jadi wali bagi dirinya apabila wali bertindak tidak baik terhadap diri dan hartanya. ${ }^{20}$ Beberapa anak yang berada di bawah perwalian yang diperlakukan kadang-kadang sedikit kasar, namun dia menyadari bahwa maksud dari walinya tersebut adalah untuk kebaikannya, sehingga dia tidak mau untuk memperbesar masalah. Berkaitan dengan harta anak, sebagian anak ada yang mengetahui, bahwa hartanya telah dialihkan atau dijual akan tetapi wali memberitahukannya bahwa penjualan itu dilakukan untuk kepentingan anak tersebut, akan tetapi sering hartanya setelah dijual baru diberitahukan. Hal ini yang kadang-kadang membuat dia sedih. Wali tidak memberikan catatan terhadap harta yang telah digunakan.

Mekanisme pengawasan terhadap wali tidak jelas. Terhadap kasus seperti di atas memang sangat diperlukan adanya pengawasan terhadap anak tersebut, sehingga wali itu bisa mengubah kebiasaannya yang tidak baik, meskipun memang penjualan yang dilakukan adalah untuk kepentingan anak yang berada di bawah perwalianya akan tetapi tetap harus ada izin lebih dahulu.

Belum adanya lembaga Pengawas yang benar-benar konsen terhadap perwalian (Baitul Mal ada tugas pokok yang lain yang lebih berat). Menurut Pasal 21 ayat (5) Qanun No. 1 Tahun 2008 tentang Perlindungan Anak, yang menjadi wali pengawas adalah Lembaga Baitul Mal. Akan tetapi mekanisme pengawasannya belum ada petunjuk, sehingga Baitul Mal hanya menunggu laporan dari anak, masyarakat atau keluarga dekat anak terhadap hal tersebut. Baitul Mal memang memilki tugas lain yang berat seperti mengelola harta agama berupa Zakat, Infak dan Shadaqah kaum muslimin, namun tugas inipun tidak kalah penting. ${ }^{21}$

\section{Upaya-Upaya Hukum dan Solusi lain yang da- pat Dilakukan Terhadap Wali yang Melalaikan Kewajiban dan Tanggung J awabnya}

\footnotetext{
20 Wawancara dengan Anak yang berada di bawah perwalian, tanggal 26 J uli 2009

21 Wawancara dengan Pegawai Baitul Mal Kota Banda Aceh, tanggal 30 J uli 2009.
} 
Upaya-upaya hukum dan solusi yang dapat dilakukan terhadap wali yang melalaikan kewajiban dan tanggung jawabnya antara lain: pertama, apabila terdapat laporan dari masyarakat terhadap wali yang melalaikan tanggung jawab dan kewajibannya maka wali tersebut harus dipanggil oleh wali pengawas dan dimitai keterangan tentang kelaliannya jika terindikasi wali melakukan hal yang dilarang oleh qanun maka sanksi yang diatur harus diterapkan (mekanisme pengawasan belum diatur, sehingga upaya ini sulit dilakukan); kedua, terhadap pengetahuan wali dan anak yang berada di bawah perwalian pemerintah dapat melakukan sosialisasi secara kontinyu dan mendalam kepada para wali dan anak-anak tersebut, agar mereka benar-benar memahami dan mengerti apa yang menjadi tugas, kewajiban dan tanggung jawabnya, sehingga dia tidak Ialai lagi; dan ketiga, perlu adanya upaya untuk membentuk lembaga pengawas khusus yang menangani permasalahan terhadap anak pada umumnya dan atau anak yang berada di bawah perwalian pada khususnya.

Pengawasan terhadap anak yang berada di bawah perwalian selama ini tidak ada, karena pengawasan tersebut tidak diatur dengan tegas maka tidak ada pengawasan yang dilakukan. Dalam qanun sudah ditegaskan, bahwa wali pengawas adalah Baitul Mal, akan tetapi mekanisme pengawasannya tidak diatur lebih lanjut. Bagi anak yang masih kecil dia tidak akan pernah mengetahui apakah dia mempunyai harta atau tidak, apakah wali yang memeliharanya selama ini menggunakan harta pribadinya atau memang harta tersebut peninggalan orang tuanya. Peraturan terhadap pengawasan memang sangat dibutuhkan. Pihak Mahkamah sudah pernah membuat seminar serta dialog tentang perlunya pengaturan tentang pengawasan terhadap anak yang berada di bawah perwalian seseorang. Masyarakat juga harus sangat berperan untuk melaporkan, apabila ada wali yang melalaikan kewajibannya dan tanggung jawabnya.

\section{Penutup \\ Simpulan}

Beberapa wali ada yang tidak membuat daftar harta benda anak yang berada dibawah kekuasaannya pada waktu memulai jabatannya dan tidak mencatat semua perubahan-perubahan harta benda, anak/ kekayaan anak yang berada di bawah perwaliannya. Wali ada yang belum menyerahkan seluruh harta anak yang berada di bawah perwaliannya padahal anak telah berusia di atas 18 tahun atau telah menikah. Masih ada wali yang tidak bertanggung jawab tentang harta benda anak yang berada dibawah perwaliannya, serta kerugian yang ditimbulkan karena kesalahan atau kelalaiannya. Berdasarkan hasil penelitian yang diperoleh menunjukkan, bahwa masih sangat sedikit wali yang mencatat harta anak yang berada di bawah perwaliannya dan ditemukan hanya 5 orang wali (5\%) yang membuat daftar harta dan mencatatnya dan ada di antara wali yang menggunakan harta anak yang di bawah perwaliannya untuk kepentingan anak tersebut (wali yang miskin 20 (20\%) dan selebihnya wali menggunakan hartanya sendiri untuk keperluan anak, sedangkan harta anak yang berada di bawah perwaliannya tersebut tidak digunakan dengan alasan ada harta yang tidak berada di bawah penguasaannya (50\%) dan ada yang mengatakan tidak akan menggunakan harta tersebut selama wali masih mempunyai harta untuk bisa menghidupi atau menyekolahkan anak tersebut (25\%).

Ada beberapa faktor yang menyebabkan wali lalai dalam melakukan kewajiban dan tanggung jawab terhadap anak yang berada di bawah perwaliannya. Pertama, faktor interen (faktor penyebab yang berasal dari dalam diri wali itu sendiri, Anggapan wali terhadap tidak pentingnya catatan harta anak yang berada di bawah perwaliannya. Kurangnya pengetahuan dari wali terhadap kewajiban dan tanggung jawabnya terhadap anak di bawah perwaliannya, pendapat wali yang menganggap bahwa anak yang berada di bawah perwaliannya memang belum bisa diberikan hartanya, meskipun dia sudah berusia 18 tahun, karena anak masih belum bisa mengatur atau mengelola uang sendiri, atau karena adanya sifat boros dalam diri anak tersebut. Kedua, faktor ektern (faktor yang berasal dari luar diri wali) yaitu: kurangnya sosialisasi dari intansi terkait terhadap aturan perwalian (penerapan sanksi); rasa kekeluargaan 
yang tinggi dari anak untuk tidak melaporkan orang yang telah menjadi wali bagi dirinya apabila wali bertindak tidak baik terhadap diri dan hartanya. Tidak J elasnya mekanisme pengawasan terhadap wali; belum adanya lembaga pengawas yang benar-benar konsen terhadap perwalian

Upaya-upaya yang dilakukan antara lain apabila ada laporan dari masyarakat, maka terhadap wali yang melakukan larangan dari qanun setelah dimintai keterangan, terindikasi harus dapat diterapkan sanksi. Sosialisasi secara terus menerus kepada para wali dan anak-anak yang berada di bawah perwalian. Selain itu perlu ada upaya pembentukan lembaga pengawas khusus yang menangani permasalahan anak pada umumnya dan atau anak yang berada di bawah perwalian pada khususnya dan adanya penerapan sanksi dalam qanun Perlindungan anak terhadap wali yang tidak menjalankan tanggung jawab.

\section{Saran}

Pemerintah seharusnya membuat aturan yang tegas yang mengatur tentang mekanisme pengawasan terhadap wali dan anak, serta harta anak yang berada di bawah perwalian seseorang, karena sekalipun sudah ada Baitul Mal sebagai wali pengawas, namun ternyata belum maksimal.

\section{Daftar Pustaka}

Alam, Andi Syamsu dan Fauzan. 2008. Hukum Pengangkatan Anak Perspektif Islam. Jakarta: Pernada media Group;

Hitami, Munzir. "Taat Hukum dan Pendidikan Akhlak". J urnal Hukum Respublica, Vol. 4 No. 1, 2004;
Idami, Zahratul. "Penetapan Perwalian Bagi Anak Korban tsunami Oleh Mahkamah Syar'iah Kota Banda Aceh". Jurnal Media Hukum Vol. 17, No. 2 Desember 2010, UMY Yogyakarta;

Lestari, Rika. "Tinjauan Yuridis Pelibatan Anakanak dalam Penyelenggaraan Pemilu". Jurnal Mahkamah Konstitusi, Badan Kajian Konstitusi Universitas Riau, Vol. II No.1/ J uni 2009, Mahkamah Konstitusi Rl;

Muhammad, Ghulam. "Sistem Hukum Kewarisan dalam Kompilasi Hukum Islam", Warta Univertaria No. 23, 2009, Universitas Medan Area;

Rosidah, Nikmah. "Faktor Penyebab Penyalahgunaan Narkotika dan Psikotropika oleh Anak (Studi Pada Lembaga Pemasyarakatan Rajabasa Bandar Lampung)". Supremasi Hukum, Jurnal Penelitian Hukum, Vol II No. 1, 2006, Fakultas Hukum Universitas Bengkulu;

Sasonggo, Wahyu. "Kajian Terhadap Putusan Perkara No. 159/ Pdt.G/ 2006/ PA. Tnd Tentang Perbedaan Agama Faktor Determinan Terjadinya Perceraian". Jurnal Yudisial, Vol. I No. 3, Desember 2007;

Summa, Muhammad Amin. 2004. Hukum Keluarga Islam di Dunia Islam. Jakarta: Rajawali Press;

Wijaningsih, Dyah. "Perubahan social dan Hukum (dalam Ancangan dan Pemikiran)", Jurnal Hukum, Vol 14, No. 1, 2004, Fakultas Hukum Universitas Islam Sultan Agung;

Wismayanti, Yanuar Farida. "Permasalahan dan Kebutuhan Anak yang berkonflik dengan Hukum di Lapas Anak Blitar". J urnal Penelitian dan Pengembangan Kesejahteraan Sosial, Vol. 12 No. 01, Januari-J uni 2007, J akarta: Kemensos RI. 